\title{
The effect of plasma from septic ICU patients on healthy rat muscle mitochondria
}

\author{
J Grip ${ }^{1,2^{*}}$, T Jacobsson ${ }^{1}$, N Tardif ${ }^{1}$, O Rooyackers ${ }^{1}$ \\ From ESICM LIVES 2015 \\ Berlin, Germany. 3-7 October 2015
}

\section{Introduction}

Even though sepsis induced organ failure is a major cause of death in ICU worldwide, the mitochondrial dysfunction associated with this is not fully characterized and there is presently no evidence of causality $([1,2])$.

\section{Objectives}

In this study we examined whether a central factor in septic plasma could affect respirational function of healthy rat muscle mitochondria.

\section{Methods}

ICU patients with severe sepsis or septic shock were recruited within $24 \mathrm{hrs}$ of admission together with agematched controls. Blood samples were centrifuged and immediately frozen. Two trials were performed and mitochondrial respiration was analyzed using an Oxygraph chamber with a Clarke-electrode in an isolation medium (containing mannitol, sucrose, Tris-base, $\mathrm{KCl}, \mathrm{MgCl}$, $\mathrm{K}_{2} \mathrm{HPO}_{4}$ and EDTA, $\mathrm{pH}$ 7.0).

1) Isolated mitochondria from rat skeletal muscle were divided and incubated for 30 minutes with plasma from patients or postoperative controls $(n=12)$. Respiration was normalized for citrate synthase (CS), which was measured using spectrophotometry.

2) Permebealized muscle fibres from rats were divided and incubated with plasma from patients or healthy controls, for 30 and 120 minutes, and analyzed for mitochondrial respiration $(n=10)$. Respiration was normalized for fibre weight.

Primary outcome was state 3 respiration, which the maximal respiration initiated with ADP and adequate energy substrates (malate and pyruvate). T-test was used for statistical comparison.

Karolinska Institute, Dept Anesthesiology and Intensive Care CLINTEC, Huddinge, Sweden

Full list of author information is available at the end of the article

\section{Results}

No differences in respirational function of the mitochondria were seen between the groups in either of the experiments. 1) State 3 respiration in isolated mitochondria were $19.9 \pm 6.7$ vs. $20.2 \pm 8.8 \mathrm{nmol} \mathrm{O}_{2} \times \mathrm{U} \mathrm{CS}^{-1} \times \mathrm{min}^{-1}$ for sepsis vs. control respectively 2) State 3 respiration for fibres incubated with septic and control plasma were after 30 minutes $2.6 \pm 0.3$ vs. $2.4 \pm 0.7$ and after $120 \mathrm{~min}$ utes $2.5 \pm 0.4$ vs. $2.5 \pm 0.6 \mathrm{nmol} \mathrm{O}_{2} \times \mathrm{mg} \mathrm{w} . \mathrm{w}^{-1} \times \mathrm{min}^{-1}$. Respiratory control ratios (state $3 /$ state 4 ) were good in all experiments (8.8-11.2), ensuring adequate quality of the mitochondria.

\section{Conclusions}

These findings indicate that the effect on muscle mitochondria in sepsis is secondary rather than directly influenced by a factor in plasma of septic patients.

\section{Grant acknowledgment}

This study was partly financed by grants from the Swedish Research Council

\section{Authors' details}

'Karolinska Institute, Dept Anesthesiology and Intensive Care CLINTEC,

Huddinge, Sweden. ' Karolinska University Hospital Huddinge, Anesthesiology and Intensive Care, Huddinge, Sweden.

Published: 1 October 2015

\section{References}

1. Singer M: The role of mitochondrial dysfunction in sepsis-induced multiorgan failure. Virulence 2014, 5:66-72.

2. Jeger $V$, Djafarzadeh $S$, Jakob SM, Takala J: Mitochondrial function in sepsis. European journal of clinical investigation 2013, 43:532-542.

doi:10.1186/2197-425X-3-S1-A623

Cite this article as: Grip et al:: The effect of plasma from septic ICU patients on healthy rat muscle mitochondria. Intensive Care Medicine Experimental 2015 3(Suppl 1):A623.

\section{SpringerOpen ${ }^{\odot}$}

(C) 2015 Grip et al.; This is an Open Access article distributed under the terms of the Creative Commons Attribution License (http:// creativecommons.org/licenses/by/4.0), which permits unrestricted use, distribution, and reproduction in any medium, provided the original work is properly cited. 